\title{
Fundamentos ideológicos del fenómeno procesal
}

\author{
POR ROBERTO OMAR BERIZONCE $\left(^{*}\right)$
}

\begin{abstract}
Sumario: I. Las ideologías en su conceptualización objetivada.- II. Ideologías en el derecho.- III. Los fundamentos ideológicos del fenómeno procesal.- IV. Los modelos típicos.- V. Los fines y objetivos del proceso civil.- VI. Los roles del juez y de las partes.- VII. La estructura del procedimiento.- VIII. La regulación del sistema probatorio.- IX. Hacia una síntesis y en la búsqueda de un sistema de valores abarcador.- X. Bibliografía.
\end{abstract}

Resumen: se propone una síntesis superadora de las antinomias que tradicionalmente han campeado en punto a los fines y objetivos del proceso civil. A partir de los valores que sustenta el Estado Democrático de Derecho, se analizan las clásicas disyunciones privatismo-publicismo, nacionalismo-internacionalismo, y la evolución de la concepción de los fenómenos procesales en general. Se trata, en definitiva, de pensar el proceso civil en la perspectiva de los derechos fundamentales.

Palabras claves: ideologías - proceso civil - derechos fundamentales

\section{Fondamenti ideologici del fenomeno processuale}

Abastract: propone una sintesi incomparabile di antinomie che hanno tradizionalmente campeado agli scopi e obiettivi del processo civile. Sulla base dei valori su cui si fonda lo Stato Democratico di Diritto, discussione classiche disgiunzioni privatismo-publicismo, nacionalismo-internacionalismo e la evoluzione del concetto di fenomeni procedurali in generale. $\grave{E}$, in breve credo il processo civile nella prospettiva dei diritti fondamentali.

Keywords: ideologie - processo civile - direitos

\section{Las ideologías en su conceptualización objetivada}

La ideología surca todas las vertientes de la vida en sociedad: la política, la economía, el desarrollo social, la cultura en todas sus manifestaciones, incluyendo

(*) Profesor Emérito Universidad Nacional de la Plata, UNLP. 
naturalmente el derecho. En sentido estricto, sin embargo, solo son consideradas ideologías las posturas comprometidas con el poder y su lucha.

En puridad, conceptualmente se trata de visiones o creencias generales que encuentran su sustento en principios y valores que, a su vez, expresan y son tributarios de profundas razones y condicionamientos sociales, económicos y culturales que inciden en determinado contexto histórico.

Esa conceptualización objetivada pretende superar y desentenderse tanto de la versión en clave marxista de dogmas falsos, cuanto del sentido peyorativo que expresa y recela del enmascaramiento de situaciones e intereses reales.

Desde luego, no es censurable el compromiso ideológico en sí, porque el pensamiento no se configura como axiológicamente neutro, sino en todo caso las posturas solapadas que no son francas y conscientes. El pensamiento se vuelve, entonces, cautivo intelectualmente y, por ende, incapaz de imaginar y construir alternativas superadoras, por el temor a pensar por su cuenta.

El tema de las ideologías se hace patente, a menudo de un modo perturbador, cuando se pone en cuestión el compromiso de los intelectuales. Es a ellos a quienes primariamente les corresponde el esfuerzo en favor de una desapasionada reflexión individual y crítica sobre las ideas, y, sobre todo, de la fundamentación de las opciones morales. La crítica a las ideologías, o mejor su descalificación, asienta precisamente en la quiebra - que ellas implican - a esa regla de oro, y que conduce inevitablemente a opciones dogmáticas sesgadas, llevando a su desprestigio. Visiones maniqueas que, traicionando aquellas premisas que justifican su propia razón de ser, se enrolan en posturas ortodoxas burdamente parcializadas, y a menudo cínicas, que se construyen de espaldas a la razón crítica y al juicio moral desapasionado. Algunos quedan así atrapados en el compromiso político militante, que implica un concepto deflacionado de la ideología, porque arrastra el peso del deber de seguir a pie juntillas y dogmáticamente la lógica de la política, cualquiera sea su color, a la que se sacrifica si fuere necesario la opción moral(1) (Judt, 2014, pp. 25, 26, 33).

De ahí que haya podido cáusticamente afirmarse que la ideología, en el sentido que varios filósofos le confirieron ya en el siglo XIX, entre ellos Marx, remite a un sistema de ideas que, bajo la apariencia de verdad absoluta, es en rigor un conjunto de relatividades que sirven - o están al servicio- a un Estado, a una clase dominante, a una secta. Todas ellas en el fondo son científicamente falsas, contaminadas, simples simulacros de la verdad que se sustentan en el pensamiento

(1) Judt, T. (2014). El peso de la responsabilidad. Buenos Aires: Aguilar. Azaola (trad.) (pp. 25, 26, 33). 
dogmático, que desdeña la libertad de pensar y crear, tanto como en el cinismo político y el nihilismo moral(2).

No se trata, claro, de refugiarse en una mistificadora "neutralidad o pureza" frente a los contenidos de los grandes conflictos que acucian al ser humano. En todo caso, actitudes semejantes reflejan en el fondo, consciente o inconscientemente, una ideología que es la de la aceptación y la conservación del statu quo. Tampoco tiene asidero la proposición que afirma — bajo cualquier circunstancia o contexto- el "fin o la muerte de las ideologías" (3), pues siempre más temprano que tarde han de sobrevenir otras ideologías que las sustituyan o, al menos, que replanteen bajo nuevas o renovadas perspectivas de las antes existentes. En todo caso podría afirmarse que solo quedaron superadas algunas construcciones políticas que se inspiraban en ciertas ideologías (4) (Bobbio, 1995, p. 51).

La concepción objetivada presupone, entonces, estar en guardia de aquellos análisis sesgados que desde las ideologías tienden a desdeñar o infravalorar la incidencia de las transformaciones sociales, culturales y económicas, que a menudo responden a otras fuerzas que se desarrollan en las sociedades modernas sin depender (y aún de espaldas) de las ideologías - y sus concepciones binarias-(5) (Marioni, 2015, pp. 431 y ss.).

Una clasificación elemental y, por ende, difusa de las categorías ideológicas imaginadas para identificar principalmente las grandes líneas de pensamiento político y económico, pero también aplicable a los demás ámbitos de la cultura, indica al menos dos vertientes genéricas: la del conservadurismo tradicionalista, de sesgo liberal-individualista que comienza a perfilarse con el Iluminismo y ha perdurado con sucesivas adaptaciones y ropajes -neoliberalismo-; y la contrapuesta del progresismo innovador, igualmente presente en todas las instancias históricas bajo diferentes expresiones. Conceptos antitéticos que se expresan y

(2) Judt, T. (2014). El peso de la responsabilidad. Buenos Aires: Aguilar (pp. 25 y ss.). Camus, A. (2005). El hombre rebelde. Buenos Aires: Losada. Luis Echávarri (trad.) (p. 289). Sábato, E. (2003). Apologías y rechazos. Buenos Aires: Seix Barral (p. 170).

(3) Bobbio, N. (1995). Derecha e izquierda. Razones y significados de una distinción política. Madrid: Taurus (p. 51). En todo caso puede hablarse de las sucesivas "crisis". El árbol de las ideologías siempre está reverdeciendo. Además, no hay nada más ideológico (...) que la afirmación de la crisis de las ideologías.

(4) Taruffo, M. (2015). Ideologie e teorie della giustizia civile, RePro. São Paulo (p. 49). En versión castellana: Ramírez Carvajal, (2003). Ideologías y teorías de la justicia civil, Proceso judicial y cultura. Una mirada global, Univ. de Medellín, FUTC (p. 23). Asimismo, en Constitucionalismo y proceso. Tendencias contemporáneas, R. González Álvarez (coord.). Lima: ARA (p. 151). Seguimos en adelante la versión de Medellín.

(5) Donde destaca la ideología del "patrimonialismo" en la formación de la cultura jurídica brasileña. 
traducen igualmente, en términos de la política como la dicotomía o díada omnicomprensiva derecha e izquierda, distinción de fuerte connotación axiológica, útil, aunque no deja de ser arbitraria y anacrónica (6).

Como lo preconiza Bobbio (1995, pp. 98-99), el análisis de las ideologías para el cientista, historiador, sociólogo, debe ser afrontado desde la imparcialidad, al margen de todo juicio de valor, de modo objetivo. Desde el atalaya del observador neutral e independiente, y no desde la visión inevitablemente sesgada del militante en cualquiera sea la causa. No se trata, entonces, de tomar partido, sino de dar testimonio de debates que siguen vivos y lo propio, añadimos, vale para el jurista; por ello, aludimos antes a las ideologías en visión objetivada.

Claro que los ideales puros, por llamarlos de alguna manera, que nacen de la pasión y la razón, resisten el paso del tiempo; son irreductibles a pesar de los buenos oficios de la razón conciliadora. Pero no son absolutos, de modo que el cientista no debe pretender erigir sus preferencias personales, desde luego legítimas e irrenunciables, en criterios generales de razón o sinrazón (Bobbio, 1995, pp. 173-174).

Precisamente, es desde aquella atalaya objetiva e independiente que un observador lúcido puede advertir mejor los múltiples entrecruzamientos y puntos de contacto que, en el devenir histórico, van acercando inevitablemente con mayor o menor intensidad las opuestas posturas dicotómicas. Así, sin renunciar a los principios y valores que personalmente abraza, puede - y debe - tentar aproximaciones y pergeñar opciones superadoras a partir de una visión triádica, la del tercero "incluyente". Esas "terceras vías" de pensamiento no solo proliferan en el imaginario político (Bobbio, 1995, pp. 53-55 y ss.), sino también en las diversas expresiones de la cultura - piénsese, v.gr., en las artes-, y el derecho no puede constituir una excepción.

A partir de estas premisas abordaremos las influencias de las ideologías en sus distintas vertientes, sobre el fenómeno jurídico en general y en el proceso judicial en particular.

\section{Ideologías en el derecho}

El derecho, típica manifestación cultural, no se construye como un sistema puro pretendidamente exento de toda contaminación ideológica, ni al margen de los influjos del poder en cada circunstancia histórica o de las propias tradiciones

(6) Bobbio, N. (1995). Derecha e izquierda. Razones y significados de una distinción política. Madrid: Taurus (pp. 98-99). Sobre el liberalismo político: Rawls, J. (1996). El liberalismo político. Barcelona: Mondadori. Domenech (trad.) (pp. 72-77). 
que conforman las estructuras sociales y económicas (Taruffo, 2015, p. 49). Las diversas concepciones del derecho -incluso las teorías pretendidamente "puras", que marcaron el apogeo del formalismo jurídico- son reflejo de las ideologías.

Cappelletti destacaba en 1968, en la nota preliminar a su obra Processo e ideologie (7), su objetivo de llamar la atención sobre los fundamentos prejurídicos o metajurídicos (ideológicos) de las normas e instituciones del derecho, y en especial del fenómeno procesal, al igual que sobre los significados y valores y fines humanos, sociales, económicos, ideológicos ocultos tras las palabras de las leyes, que consciente o inconscientemente, inspiran toda la interpretación doctrinal y judicial, y constituyen, al fin de cuentas, el verdadero "espíritu" de todo el sistema jurídico.

Daba cuenta, también, del "compromiso" metodológico que cabe asumir frente al tradicional método de estudio típicamente escolástico, dogmático y formalístico (que tiene por objeto la búsqueda de una ciencia "pura" e ideológicamente "neutral"), para superarlo mediante una nueva concepción del derecho como fenómeno social y de la ciencia jurídica como ciencia sociológico-valorativa, y no formal, una ciencia de problemas prácticos y no de sistematizaciones conceptuales abstractas; de resultados concretos y de elecciones creativas, y, por ende, responsables, y no de conclusiones automáticas.

Precisamente - afirma - la visión ideológica propone que el estudio del derecho no debe prescindir del análisis crítico de la función de las normas $-\mathrm{y}$ de los resultados concretos de su aplicación-, en conexión con los valores inspirados en concepciones económicas, sociales y culturales (visión cuya necesidad se acentúa en épocas de crisis). Cuando las estructuras jurídicas ya no respondan a las nuevas exigencias y necesidades sociales, el jurista (abogado, juez, doctrinario) tiene que asumir (compromiso) el deber científico — además de moral— de centrar su labor investigadora en aquellas exigencias, y partiendo de éstas hacer su propia contribución, por modesta que sea, a la construcción de un sistema "nuevo", más realístico y más humano (8).

\section{Los fundamentos ideológicos del fenómeno procesal}

Lo propio cabe a propósito de los fundamentos ideológicos del fenómeno procesal, a los que alude el recordado maestro italiano en Giustizia e societá (1972).

(7) Cappelletti, M. (1974). Proceso, ideologías, sociedad. Buenos Aires: EJEA. Sentís Melendo y Banzhaf (trad.).

(8) Para un análisis crítico del legado de tendencia dejado por estas ideas: Giussani, A. (2013). Alla ricerca dello spirito della sinistra degli anni 70 nella giustizia civile italiana. São Paulo: RePro (pp. 345 y ss.). 
El análisis ideológico abierto y estimulado por la visión comparativa —sostiene-, muestra la relatividad de los principios, normas e instituciones procesales, por los condicionantes históricos (derecho anglosajón) e ideológicos (países socialistas); y ha conducido a la enumeración de nuevas categorías que están en la base de una renovada ciencia del proceso. Así, la relación entre poderes del juez y atribuciones de las partes, que adquiere dimensiones salientes (publicización, privatización); el resurgimiento del ideal oralístico, la decadencia de las pruebas legales; la construcción del sistema de justicia constitucional, social y transnacional, en fin.

El proceso civil ha sido tradicionalmente considerado una rama extremadamente técnica del derecho, razón por la cual solo muy raramente se habían analizado sus fundamentos ideológicos, sus premisas filosóficas, sus reflejos políticos y sociales. Un análisis semejante se torna indispensable, una vez que se toma conciencia que ninguna técnica jurídica es un fin en sí misma, y que ninguna es neutral desde el punto de vista ideológico (Cappelletti, 1974, pp. 34 y ss.; pp. 83-90).

Se reproduce, en definitiva, en el debate sobre las instituciones del proceso, el contrapunto central que se plantea entre el individuo y sociedad (o mejor el Estado), que enfrenta en el plano ideológico a varias visiones binarias: el liberal individualismo "privatista", de la conservación, y a las diversas tendencias progresistas "publicistas" (9) (Cappelletti, 1974, pp. 85-87); también aquella que contrapone a la tradicional concepción nacionalista el ideario transnacional o internacionalista (Cappelletti, 1974, pp. 87-88).

El proceso es esencialmente un instrumento al servicio de finalidades y objetivos de política jurídica en general, y de política judicial en particular. El diseño de una y otra, a su vez, depende de elecciones que en esencia son ideológicas y están influenciadas por valores que se consideran prevalecientes y dignos de ser realizados en un determinado contexto histórico y socio-político, antes que jurídico. Un modelo procesal nace de la combinación de opciones ideológicas y de instrumentaciones técnicas (Taruffo, 2015, p. 49). El Código procesal -afirmaba Couture (1928, pp. 144-145)—, no es una especulación académica sino una obra política, porque el proceso es una idea teleológica.

La dimensión ideológica incide directamente sobre los modelos de proceso civil, en diversos de sus elementos configurativos, en especial sobre: a) sus fines $u$ objetivos; b) la distribución de papeles o roles que se asignan al juez y a las partes; c) la estructura del procedimiento; d) la regulación de las pruebas (Taruffo, 2015,

(9) Sobre las corrientes de pensamiento dominantes en la actualidad, entre otras obras: Zanetti, J. H. (2007). O modelo constitucional do processo civil brasileiro. Lumen Juris. González Álvarez, R. (2007). De los orígenes del proceso al neoprocesalismo. Constitucionalismo y proceso. Tendencias contemporáneas. (pp. 167 y ss.). 
p. 196). Vinculados con tales factores principales, operan, asimismo, entre otros: e) los métodos alternativos de solución de conflictos y la "desjudicialización"; f) los mecanismos de ejecución de la sentencia; g) la operatividad del principio o máxima de cooperación; h) el tratamiento de la tutela de los derechos colectivos, incluyendo los derechos sociales, económicos y culturales.

\section{Los modelos típicos}

Para el análisis de la configuración e incidencia de los distintos modelos, conviene distinguir sucintamente al menos las dos últimas etapas en que se consolidaron sus rasgos más típicos: I) aquella en la que se enfrentan las ideologías liberal-individualista - que en lo político y económico enraízan en el Iluminismo y se despliegan con los movimientos revolucionarios de fines de siglo XVIII-, y aquellas otras de tinte social (Klein), que asoman hacia la última mitad del XIX para afianzarse en el siguiente; II) la más reciente en la que opera la transformación de los modelos procesales, aún en curso, que puede advertirse a partir de la segunda mitad del siglo anterior. Es el tiempo en que aquella visión binaria primigenia de los fenómenos procesales se transforma y enriquece desde nuevas propuestas para configurar el neoliberalismo procesal, de la "conservación", de sesgo "dispositivista", vis a vis la del progreso social, "publicístico", enmarcada en el constitucionalismo y las convenciones humanitarias. Todavía, por último, los loables esfuerzos superadores y de síntesis para tratar de amalgamar al menos algunos elementos de las tradicionales visiones dicotómicas.

\section{Los fines y objetivos del proceso civil}

La cuestión de establecer cuáles son los objetivos y finalidades del proceso civil remite a elecciones que son esencialmente ideológicas. Así, decidir que debe ser orientado a resolver controversias sobre la base de la libre competición de las partes privadas, o ya asumir, por el contrario, que debe ser orientado a la producción de decisiones justas. Un modelo procesal nace de la combinación de opciones ideológicas y de instrumentaciones técnicas que, a diferencia de aquellas, son neutras a los valores (Taruffo, 2015, pp. 194-196).

La ideología liberal-individualista, de la conservación, concibe al proceso como un ámbito en que se manifiesta y prevalece la autonomía de la voluntad y la libertad irrestricta de las partes, que tienen a su disposición todos los instrumentos procesales para desarrollar una competencia en la que se discuten cuestiones de su exclusivo interés, ante la cual el juez no puede pasar de ser un simple espectador - verdadero "convidado de piedra" - que se limita a asegurar la corrección del trámite y arbitrar el conflicto dándole la razón al vencedor. En ese contexto, la búsqueda de la verdad procesal perdía toda relevancia, absorbida por el fenómeno 
formal de la subsunción en el cual se agotaba el paradigma racionalista(10). Y, en el diseño técnico, por consecuencia, prevalece la forma escrituraria y la fragmentación del procedimiento.

En cambio, en el pensamiento superador que constituyó la ideología de la función social (Klein) se asignó al proceso la finalidad de realizar el derecho material, y con ello, su consustancial naturaleza pública (11) - publicísmo- y no privada. De ahí que el juez pasaba a asumir un rol activo preponderante en la dirección e instrucción de la causa, precisamente para realizar aquellos objetivos que traían ínsitos la eficiencia y funcionalidad del proceso, a fin de asegurar la justicia y legitimidad de las decisiones.

Con la irrupción hacia mediados del siglo anterior de la "edad de las garantías"(12) y aún de la "cultura de las garantías" (Taruffo, 2015, p. 197), junto con la amplificación y perfeccionamiento del bill of rights, el catálogo de los nuevos derechos, especialmente, los derechos económicos, sociales y culturales, y su reconocimiento en las convenciones humanitarias, la jurisdicción se reafirma como función pública y el proceso civil adquiere nuevas notas típicas. En ese sentido, la constitucionalización de las garantías procesales puede considerarse como la máxima consolidación, o el punto de llegada de la concepción publicística del proceso civil (Taruffo, 2015, p. 177). La tutela judicial eficiente, con sus correlatos, pasa a integrar el "núcleo duro" de la Constitución y las convenciones transnacionales; y ello incide en los fines del proceso que, ahora, también debe satisfacer puntualmente los derechos fundamentales y aún los convencionales que provienen de los tratados sobre derechos humanitarios, que el Estado se obligó a cumplir ante la comunidad internacional. El compromiso consiste, en el nuevo escenario, en instrumentar el proceso civil de modo que resulte accesible a todos, rápido y sin demoras excesivas, con costos razonables y capaces de satisfacer adecuadamente las necesidades de tutela de todos los ciudadanos. Un régimen de enjuiciamiento

(10) Baptista Da Silva, O. A. (2004). Processo e ideología: o paradigma racionalista. Forense. La verdad procesal acabaría convirtiéndose en la búsqueda de la realidad burguesa en cada caso concreto, condicionada por varios mitos estratégicamente diseminados, tales como el de la neutralidad o de la seguridad jurídica.

(11) Couture, E. J. (1928). Fundamentos del Derecho Procesal Civil. Buenos Aires: Depalma (pp. 144-147). Taruffo, M. (2015). Ideologie e teorie della giustizia civil. RePro. São Paulo (p. 27).

(12) Morello, A. M. (1998). Constitución y proceso. La nueva edad de las garantías jurisdiccionales. LEP.

Comoblio, L. P. (1994). I modelli di garanzia costituzionale del processo. Studi in onere di Vittorio Denti. Cedam (pp. 297-381). Andolina, I. y Vignera, G. (1994). Il modela costituzionale del processo civile italiano (pp. 13 y ss.). 
civil, en suma, adecuado con el modelo constitucional de proceso (13), superador de la concepción decimonónica de la justicia civil como "bien privado" (14).

\section{Los roles del juez y de las partes}

El papel que entre nosotros desempeña el juez en el proceso civil viene prefigurado por las variables estructurales de la tradición del civil law continental europeo, que aún perduran en Iberoamérica, en cuanto a la naturaleza del órgano jurisdiccional. Se trata de jueces técnicos - juez jurista- que se insertan en una carrera burocrática profesional, en la que ingresan por métodos diversos de selección, cuya misión, influida por lo anterior y especialmente por desenvolverse con sujeción a un esquema "piramidal" jerárquico, se ve acotada fuertemente en cuanto al poder de creación del derecho por interpretación pretoriana, insertos en un sistema que rechaza la formación y virtualidad de los precedentes. Son rasgos denotativos de una ideología más cercana a la liberal-individualista, que en este aspecto ha seguido prevaleciendo hasta el presente (15).

El rol que se reserva al juez en el diseño del proceso civil ha sido, sin duda, el ámbito en el cual las ideologías se enfrentan con mayor ahínco. Siempre enmarcado en el principio dispositivo, la bilateralidad y amplia contradicción, se pone en cuestión la mayor o menor amplitud y densidad de los poderes-deberes judiciales, su activismo, en simétrica correspondencia con los que vienen reservados a las partes. La confrontación se libra principalmente en el terreno propio de la dirección, ordenación e instrucción probatoria, esparciéndose en otros segmentos del régimen procedimental —medidas cautelares y de urgencia, ejecución de la sentencia, entre otros-.

(13) Zanetti, Junior H. (2007). O modelo constitucional do processo civil brasileiro. Lumen Juris (pp. 183 y ss.). Freitas Camara, A. (2015). Dimençâo processual do principio do debido proceso constitucional. Der. Procesal, Rev. dos Trib. São Paulo (pp. 17 y ss.). Nunes, G. E. S. (2016). Proceso civil democrático, contraditorio e novo Código de Processo Civil. RePro (pp. 15 y ss.). Silveira, D. G. (2015). Direito ao contraditorio. RePro (p. 69). Hemos de seguir estas obras como sustento, entre otras, para el capítulo final conclusivo de estas reflexiones.

(14) Taruffo, M. (2015). Ideologie e teorie della giustizia civile. RePro. São Paulo (pp. 29-30). Donde se resalta los efectos desvastadores del neoliberalismo, sobre el modo de concebir y regular la justicia civil.

(15) Berizonce, R. O. y Ferrand, F. (2011). Lois modèles et Traditions nationales. Procedural Justice. XIV IAPL World Congress, Heidelberg (pp. 115-116). Oteiza, E. D. (2013). América Latina. Cultura y proceso civil. En Proceso judicial y cultura. Una mirada global. Medellín: Universidad de MedellínFUTC (p. 199). Donde se interroga sobre cuánto pervive del pasado en las formas de administración de justicia y especialmente de la tradición española (pp. 209 y ss.). 
Es bien sabido que desde la perspectiva tradicional de sesgo liberal-individualista se alienta la negación, o la restricción en variada intensidad, de las potestades judiciales, sobremanera en punto a los poderes de iniciativa probatoria autónoma. En contraposición, desde el modelo de la ideología "publicista" no solo se asienta al juez en función de dirección del proceso, sino que, con no menos insistencia, se le atribuyen poderes de instrucción autónomos - tendencia que es sabido prevalece en la gran mayoría de los ordenamientos iberoamericanos(16)-. El reconocimiento al juez de un papel activo en el descubrimiento de la verdad de los hechos controvertidos, con la potestad de ordenar de oficio la adquisición de pruebas relevantes, aunque no hubieran sido propuestas por las partes, resulta consectario necesario de los fines públicos del proceso civil que está orientado a la obtención de decisiones intrínsecamente justas, las cuales dependen casi siempre del esclarecimiento de la verdad de los hechos(17).

En la confrontación entre ambas posturas afloró el denominado "garantismo procesal" (18), considerado por sus críticos como una expresión sesgada del garantismo jurídico, por la ausencia de razón filosófica, política y epistémica (19). Se trata en verdad de una corriente tardíamente pergeñada al margen de los avances del Estado constitucional de Derecho, y que puede afirmarse se agota en los postulados de la ideología liberal-individualista, privatista (20).

(16) Parra Quijano, J. (2004). Racionalidad e ideología de las pruebas de oficio. Bogotá: Temis (pp. 93 y ss.). Línea de tendencia que confirma el reciente ordenamiento de Brasil en vigor desde 2016 (artículos 370, 139, 369): Arruda Alvim Wambiert, T. y Otros (2015). Primeiros comentarios ao Novo Código de Processo Civil. Rev. dos Trib., São Paulo (pp. 641-644). Asimismo, el Código General del Proceso de Colombia, también en vigor desde 2016 (artículos 42 inc. 4, 43 y cctes.).

(17) Taruffo, M. (2015). Ideologie e teorie della giustizia civile, RePro. São Paulo (pp. 198-200). Chiarloni, S. (2010). Reflexiones microcomparativas sobre ideologías procesales y comprobación de la verdad. RDP. Santa Fe: Rubinzal-Culzoni (pp. 559 y ss.; 105 y ss.). Parra Quijano, J. (2004). Racionalidad e ideología de las pruebas de oficio. Bogotá: Temis (pp. 6-8). Peyrano, J. W. (1978). El proceso civil. Principios y fundamentos. Buenos Aires: Astrea (pp. 83, 337 y ss.). Peyrano, J. W. (2008). Sobre el activismo judicial. Buenos Aires: La Ley (pp. 837 y ss.). Pico Junoy, J. (2007). El juez y la prueba. Barcelona: Bosch (pp. 117 y ss.).

(18) Cipriani, F. (2003). Il processo civile italiano tra efficienza e garanzie. Rev. Trim. Dir. e Proc. Civ. Milán. Cipriani, F. (2003). Batallas por la justicia civil. Ensayos. Lima: Cultural Curzo. VV. AA., (2004). Proceso civil e ideología. Montero Aroca, (coord.). Tirant lo Blanch. Alvarado Velloso, A. (2004). Debido proceso vs. pruebas de oficio. Bogotá: Temis.

(19) Monroy Galvez, J. F. (2006). Y al final del día, ¿qué es el garantismo procesal civil? Rev. Iberoam. Der. Proc. (pp. 7 y ss.). González Álvarez, R. (2006). De los orígenes del proceso al neoprocesalismo. Constitucionalismo y proceso. Tendencias contemporáneas.

(20) Pico Junoy, J. (2004). El derecho procesal entre el garantismo y la eficacia: un debate mal planteado. Rev. Iberoam. Der. Proc. (pp. 253 y ss.). 
Para desbaratar sus premisas, baste advertir — como se ha señalado agudamente (21) - que parece a esta altura de una lógica incontrastable que "un sistema puede no inspirarse en la ideología del liberalismo del ochocientos, sin con esto dejar de ser democrático, y sobre todo sin resultar autoritario o totalitario solo porque atribuye un rol activo al juez en la adquisición de las pruebas". Una cosa es el juez potencialmente "activo" al integrar las iniciativas probatorias de las partes, inserto en un contexto procesal en el cual estén aseguradas las garantías procesales en el ámbito de un sistema político democrático, mientras otra cosa completamente diversa es el juez inquisidor en un sistema político y procesal de estampa autoritaria. En los ordenamientos procesales propios del moderno Estado de Derecho Democrático, donde está asegurado el principio dispositivo y las garantías de la defensa y del contradictorio entre las partes, el reconocimiento al juez de poderes más o menos amplios de iniciativa probatoria no transforma el esquema procedimental en inquisitorial o autoritario, ni tiene absolutamente nada que ver con regímenes políticos de ese tipo. Si bien no se trata de una opción puramente "técnica", sino por el contrario de una elección de carácter sustancialmente ideológica, en el reconocimiento de los poderes del juez, las ideologías que aquí están en juego no son aquellas que inspiran las concepciones políticas generales.

Lo que parece decisivo, en la actual instancia de desarrollo del Estado Democrático de Derecho, es la perspectiva de una nueva y superadora configuración de los poderes de los jueces (22). Con el fenómeno de la publicización o socialización procesal había operado la distinción entre el objeto del proceso, vinculado y dependiente de los intereses específicos de las partes deducidos en juicio, del proceso en sí, percibido como instrumento del Estado para la tutela efectiva de los derechos. Ello fue lo que generó para el juez un deber concreto de búsqueda de un resultado intrínsecamente justo, no simplemente formal, orientado a la materialización de la justicia como resultado final de la función pública jurisdiccional. De su lado, la constitucionalización de las garantías procesales, tanto como su mayor amplitud protectoria por la consagración del derecho fundamental de la tutela judicial eficiente y sus consectarios, vinieron a incidir en el reforzamiento del esquema publicístico y, con ello, de los poderes-deberes ordenatorios e instructorios del juez, que resultan inherentes a la función de juzgar(23).

(21) Taruffo, M. (2007). Poderes probatorios de las partes y del juez en Europa. Rev. Iberoam. Der. Proc. (pp. 305 y ss., especialmente pp. 324-325); Taruffo, M. (2007). Cultura y proceso (pp. 198-200).

(22) Sobre el tránsito del Estado de Derecho al Estado Constitucional y los caracteres generales del Derecho Constitucional actual: Zagrebelsky, G. (2005). El derecho dúctil. Trotta (p. 9).

(23) Barbosa Moreira, J. C. (1984). Breves reflexiones sobre la iniciativa oficial en materia de prueba en Libro Homenaje al Prof. Jaime Guasp, ed. Comares (pp. 156 y ss.). Pico Junoy, J. (2004). El juez y la prueba (pp. 118-121); Barbosa Moreira, J. C. (1984). El derecho procesal entre el garantismo y la eficacia: un debate mal planteado (pp. 253 y ss.). 
En una etapa caracterizada por el encumbramiento de los derechos fundamentales humanitarios, a partir de su recepción explícita en los textos constitucionales - en los diversos países de Iberoamérica desde los años 80-, y en las convenciones humanitarias, la imposición de acciones positivas al Estado ha venido a repercutir decisivamente en la misión jurisdiccional y los poderes asignados a los jueces. No solo por la consagración de un generoso catálogo de nuevos derechos, sino especialmente por el reconocimiento del derecho de igual linaje a la tutela judicial efectiva, con su correlato del aseguramiento de las garantías fundamentales del proceso, que descansa en la magistratura. Se originan así renovadas responsabilidades reflejadas tanto en el compromiso por la fiel y concreta operatividad de aquellos derechos y garantías fundamentales sustantivos, como, además, por el manejo y aún el diseño pretoriano de técnicas y procedimientos adecuados. La constitucionalización de ciertos derechos y situaciones necesitadas del trato preferente -derechos económicos, sociales y culturales en general, derechos colectivos de tercera y cuarta generación, de consumidores y usuarios, del ambiente, etc.-, verdaderos derechos "sensibles" pertenecientes a personas o grupos vulnerables o desfavorecidos, incide directamente sobre la concepción de la propia jurisdicción - ahora de sesgo especialmente protectorio-y, por añadidura, en los poderes judiciales sustantivos - funciones de garantía- y procesales. Es en este último cuadrante que aquí nos ocupa, donde se asienta una inédita relación entre los protagonistas del proceso, caracterizada por el reconocimiento de mayores prerrogativas procesales en manos de los jueces, siempre supeditadas a la observancia irrestricta de la garantía del contradictorio. Bajo esa concepción aflora, entre sus deberes - como lo ha subrayado nuestro más Alto Tribunal(24) - el de asumir un rol activo y desplegar particular energía para hacer efectivo el mandato constitucional dirigido a la protección de los derechos fundamentales. En el marco de una verdadera justicia "de acompañamiento" o protección(25), se reconoce a los jueces poderes suficientes para articular por sí una forma de protección jurisdiccional capaz de impedir la violación de los principios y reglas que edicta la ley suprema (Marinoni, 2013, pp. 370-371). Se los emplaza en el centro de la escena en una posición exorbitante como gestor activo, controlador y garante del interés general comprometido en el conflicto. Les cabe la aplicación de novedosos procedimientos y técnicas, diseñadas por la legislación o por los propios jueces,

(24) CSN, 20-6-2006, “Mendoza B. A. y otros c. Estado Nacional y otros”, tratándose de la tutela del medio ambiente; 3-2-2009, "Rosniakwoski R. C.", La Ley (p. 272), vinculado a la seguridad colectiva de personas y bienes.

(25) Monroy Galvez, J. F. (1986). jurisdicción protectora. Buenos Aires (pp. 3005 y ss.); Monroy Galvez, J. F. (1986). Un nuevo modelo de justicia. Buenos Aires: La Ley (pp. 800 y ss.); Monroy Galvez, J. F. (1989). La Corte Suprema en acción. Buenos Aires: Abeledo-Perrot/LEP (pp. 11 y ss.); Monroy Galvez, J. F. (2005). El proceso justo. Buenos Aires: Lexis Nexis/LEP (p. 651). Berizonce, R. O. (2018). Regulación procesal de las tutelas diferenciadas en la Constitución. Anales F.C.Jy S., UNLP (p. 835). 
como instituciones equilibradoras y compensadoras de las situaciones concretas de las partes en litigio (26), con la finalidad de asegurar el resultado útil de la jurisdicción. Bien que, enmarcados en los principios básicos del contradictorio y de la colaboración cada vez más ensanchada de las partes, vienen a equilibrar aquellos poderes. Cuán relegadas y desacompasadas han quedado, entonces, aquellas visiones ideológicas puramente negativistas.

El cuadro de situación se completa desde la doctrina más actualizada con el encumbramiento e inserción del principio o máxima de cooperación o colaboración. Originado en el derecho alemán, supone una nueva y superadora concepción del fenómeno procesal, que es considerado como un proceso de comunicación, formación de opinión y decisión, que por definición es abierto, argumentativo y flexible. Desde esa perspectiva, el proceso consiste, entonces, en un discurso racional en el que el diálogo debe ser efectivo, basado en narrativas con pretensión de veracidad, claras y completas, de modo que se posibilite que las partes puedan ejercer su libertad (realicen elecciones, ejerzan opciones) de modo adecuado, p.e., realizando pedidos pertinentes y requiriendo la producción de pruebas conducentes y útiles. Es en ese contexto que se insertan y destacan los poderes del juez, que son de colaboración (stricto sensu) o auxilio, de esclarecimiento, de información y advertencia, de debate y de indicación. En ese marco y con una renovada visión del fenómeno procesal, se torna posible a las partes - por medio de un tipo de conducta frente al proceso- participar en la gestión procesal(27).

Bajo ese prisma ha sido entendido como un tertium genus entre los principios dispositivo e inquisitorio, una fusión entre ambos, o bien descripto como una actividad de asistencia o de conducción desempeñada por el juez, condicionada o paralela al ejercicio de ciertos derechos y deberes que corresponden a las partes (28). De algún modo, resulta funcional a un intento de superación de las visiones antitéticas clásicas.

(26) Es lo que Dimarco denomina instituciones de "neutralización de desigualdades" (Instituçoes de Direito Processual Civil. Malheiros. p. 208). Berizonce, R. O. (2018). Regulación procesal de las tutelas diferenciadas en la Constitución. Anales F.C.J y S., UNLP (pp. 838-841).

(27) Greger, R. (2012). Cooperaçâo como principio processual. RePro (pp. 123 y ss.). Kochen, R. (2016). Introduçâo as raízes históricas do principio da cooperaçâo. RePro (pp. 75 y ss.).

(28) Kochen, R. (2016). Introduçâo as raízes históricas do principio da cooperaçâo. RePro. (p. 108). De Souza, A. C. (2013). O principio da cooperaçâo. RePro (pp. 65 y ss.) Se trata precisamente de revalorizar la participación procesal de las partes: Cabral, A. (2016). Convençôes processuais. Bahía (p. 106). Berizonce, R. O. (2017). Las estructuras cooperativas y consensuales de normatividad: ¿hacia la superación de la cultura del litigio? Buenos Aires: Rubinzal-Culzoni (p. 61). 
La doctrina brasileña ha trabajado insistente y fecundamente el tema (29), que ahora se recoge en el nuevo CPC, con singular relevancia sistemática (30).

\section{La estructura del procedimiento}

La incidencia de las distintas posturas ideológicas se manifiesta igualmente en los aspectos técnicos de la estructura de los procedimientos. $\mathrm{Al}$ menos $-\mathrm{y}$ sin perjuicio del clásico debate en torno de la oralidad(31)—, cabe resaltar diversos aspectos centrales: a) la elaboración y rango de los tipos procesales; b) en correlato con lo anterior, la configuración de los procesos especiales, los alcances de la "especialidad" y las razones en que se sustentan; c) la distribución del onus del tiempo entre los contrincantes; y d) la admisión y alcance de acciones preventivas.

Desde la visión liberal-individualista "privatista" ha prevalecido el principio de la universalización, concebida como "ordinarización" de las técnicas y soluciones procedimentales, en paralelo con la búsqueda de las "uniformidades" de que se nutren las ciencias naturales y las ciencias lógicas. Sin embargo - como se ha resaltado agudamente (Baptista Da Silva, 1993, pp. 163-164) - al despreciarse las diversas situaciones que se ensalzan en el plano del proceso, la aplicación de las metodologías de las ciencias experimentales y la búsqueda de "generalidades" ha conducido a enarbolar el principio de ordinariedad, que supone conferir un mismo y único tipo procedimental para la canalización de todos los conflictos, con prescindencia de la materia o derecho sustantivo que se discute y, sobre todo, de la condición y situación de los sujetos involucrados. Concepción aquella que se inspira en la ilusión de la neutralidad del proceso en relación con el derecho material.

Mientras se pregonaba la universalización — “ordinarización”-, en cambio, se consagraban procedimientos especiales para la tutela de determinados derechos,

(29) Dimarco, C. R. (2015). O novo Código de Processo Civil brasileiro e a ordem processual civil vigente. RePro (p. 63.) Arruda Alvim Wambiert, T. y Otros (2015). Primeiros comentarios ao Novo Código de Processo Civil. Rev. dos Trib. São Paulo (pp. 641-644). Asimismo, el Código General del Proceso de Colombia, también en vigor desde 2016 (artículos 42 inc. 4, 43 y conc.), (pp. 11171119). De Pinho, H. D. B. y Alves, T. M. (2015). O cooperaçâo no novo CPC. Recuperado de www. civilprocedurereview.

(30) Se adopta un modelo de colaboración con la explícita y amplia imposición a las partes del deber de cooperación entre sí y de cada una de ellas con el juez (artículos $6^{\circ}$ ) y, al propio juez, el deber de dialogar con las partes (artículos 9, 10 y conc.): Arruda Alvim Wambiert, T. y Otros (2015). Primeiros comentarios ao Novo Código de Processo Civil. Rev. dos Trib. São Paulo (pp. 641-644). Asimismo, el Código General del Proceso de Colombia, también en vigor desde 2016 (artículos 42 inc. 4,43 y conc.).

(31) Por todos: Cappelletti, M. (1962). La testimonianza della parte nell sistema delloralita. Dott. A. Milano: Giuffré ed. Cappelletti, M. (1972). La oralidad y las pruebas en el proceso civil. Buenos Aires: Ejea. 
privilegiados en la escala axiológica - como el derecho de propiedad, en sus diversas manifestaciones-, persiguiendo diferenciadamente la efectividad y rapidez de las decisiones. Se facilitaba una cognición sumaria y superficial que permitía resguardar el derecho en base apenas a la verosimilitud y, aún, asegurando la ejecución mandamental de las decisiones. Sistema naturalmente inequitativo y contradictorio (32), asociado a la creación de títulos ejecutivos extrajudiciales por el propio acreedor (33). Desde el hontanar "publicistico" se replica que semejante visión ideológica ha quedado superada en el Estado de Derecho contemporáneo, donde el principio de igualdad en concreto exige procedimientos diferenciados para tutelar derechos y situaciones preferentes, "sensibles" en la escala valorativa. Como expresa el recordado maestro gaúcho, el principio de igualdad así entendido exige que se trate de modo desigual a los desiguales, instituyendo determinados "privilegios". Y, de hecho, la "universalización" que supone el proceso ordinario se torna anacrónica y ha de ceder frente a los tipos diferenciados sumarios (34). No cabe admitir que el proceso civil vaya a desligarse del papel que el derecho material y los derechos fundamentales desempeñan en la sociedad. De ahí que el derecho al procedimiento adecuado se considere corolario del derecho fundamental a la tutela jurisdiccional efectiva (Marinoni; Arenhart y Mitidiero, 2015, pp. 35 y ss.).

La misma idea de neutralidad del proceso ha estado presente en la concepción de los procesos especiales. En esa perspectiva, las específicas técnicas procesales que se aplican para abastecer las diversas situaciones especiales, se sustentan en simples razones de celeridad procesal y mejor tratamiento de las causas, lo cual ha desembocado en la experiencia legislativa en una malsana proliferación de los procesos especiales, fenómeno siempre inquietante que se suma a la disfuncionalidad del proceso madre de cognición plena. Privatistas y publicistas han asistido sin otras respuestas a este escenario.

(32) Marioni, L. G. (1993). Observaçôes a partir de uma visao da ideología no processo civil. Rev. Jurídica. Curitiba. Se establecía un contrasentido: por un lado, los empresarios disponían de una justicia expeditiva especializada para tratar de sus negocios, por otro lado, no existía sino una justicia inefectiva para juzgar las demandas de sus adversarios, (...) causas en que los actores fuesen ciudadanos comunes (p. 137, cit.).

(33) Barbosa Moreira, J. C. (2006). La significación social de las reformas procesales. Buenos Aires: Rubinzal-Culzoni ed. (pp. 439 y ss.). Ciertos acreedores quedan autorizados a buscar la satisfacción de sus créditos por vías mucho más expeditivas que las abiertas a otros. Se ha llegado al extremo de atribuir fuerza ejecutiva a documentos creados por acto unilateral del acreedor bancario y financiero, sin la participación del deudor - fenómeno que la tradición reservaba a los créditos fiscales- (pp. 445-446).

(34) Baptista De Silva, O. A. (1993). A "plenitud de defesa" no processo civil. En As garantías do cuidadâo na Justiça. São Paulo: Saraiva (pp. 163-164). Asimismo: Chiarloni, S. (1975). Introduzione allo studio del diritto processuale civile. Torino (pp. 24-15). 
Con la irrupción del Estado Democrático de Derecho - como ya quedó resaltado- los derechos fundamentales suponen la configuración de ciertas tutelas diferenciadas y preferentes que los aseguren en su plenitud, en particular para los derechos "sensibles". Tales preferencias valorativas a tono con los sentimientos y valores comunitarios que recoge la Constitución, se erigen, entonces, como fundamento válido prioritario y, como regla, excluyente que sustenta la especialidad del trato procesal(35). El tipo procesal a través del cual se canalizan generalmente es el de cognición plena, aunque abreviado - plenarios abreviados y abreviadísimos-, con operatividad de las medidas satisfactivas o de urgencia.

El modo cómo en el proceso civil se distribuía la carga del tiempo entre las partes, significaba un costo que debía ser soportado por quienes demandaban la tutela jurisdiccional, lo que venía a reforzar una lógica de poder. Así en los sistemas estructurados de manera excluyente sobre el proceso de conocimiento común y pleno, en el que la declaración del derecho en el caso concreto sobreviene recién al cabo de una cognición plena, exhaustiva y naturalmente demorada. Una visión sin duda funcional al liberalismo clásico (Marinoni; Arenhart y Mitidiero, 2015, pp. 393 y ss.).

En contraposición, las tutelas anticipatorias y las técnicas de sumarización tienden a eliminar tales ventajas, en tanto suponen la inversión del onus del tiempo al exceptuar el principio de la nulla executio sine título, fruto del mito de la búsqueda de la verdad. Se trata, en definitiva, de desincentivar el interés de la parte económicamente más fuerte en la duración del proceso, por medio de medidas que, aunque no compongan definitivamente el conflicto, al menos brindan soluciones puntuales en tiempo razonable, sobre la base siempre del buen derecho aparente que ostenta quien pretende el pronunciamiento. Se persigue, en definitiva, atender los derechos fundamentales de acción y defensa, brindando tratamiento igualitario en concreto a los contrincantes (36).

Por otro lado, la dinámica del poder liberal individualista suponía condicionar la existencia del ilícito civil a la comprobación del daño, con lo que quedaba excluida de la tutela jurisdiccional la mera amenaza del derecho y la intervención preventiva. Es que ello implicaba - y por lo mismo resultaba inadmisible- el abandono de la posición neutral del juez, por medio de una intervención preventiva

(35) Sobre las tutelas diferenciadas en general: Proto Pisani, A. (1996). Lezioni di Diritto Processuale Civile. Napoli: Jovene. pp. 5 y ss.; Proto Pisani, A. (2005). Necessitá di scogliere i nodi e gli equivoci della espressione: tutela giurisdizionale diferenziata (pp. 281 y ss.). Hemos desarrollado ampliamente el tema en Tutelas procesales diferenciadas.

(36) Marinoni, L. G. (1996). Novas linheas do Processo Civil; (p. 75). De Lazzarie, E. (1996). La cautela material. Hacia una justicia más efectiva. XVII Congreso Nacional de Derecho Procesal. Buenos Aires: La Ley (pp. 558 y ss.). 
aún ajena a la voluntad de las partes, restándoles autonomía. La tutela jurídica, de ese modo, bajo el prisma de la concepción individualista, se agotaba en su función indemnizatoria, descartando aquella especial inhibitoria(37), en perjuicio notorio de la situación de las víctimas perjudicadas libradas a la sola e insuficiente actuación policial administrativa (38).

\section{La regulación del sistema probatorio}

El tema de la prueba es tal vez el que presenta las más profundas implicaciones culturales, una de las cuales está conectada con la ideología del proceso civil y sus finalidades (39). La determinación de la verdad de los hechos constituye el eje distintivo, según sea que se lo considere como un dato irrelevante - concepción privatista- o ya, por el contrario, se si erige como condición de su finalidad resumida en el logro de una decisión justa, en cuanto basada en una determinación verdadera de los hechos - concepción publicística-. Lo propio ocurre con el método, que lleva a la determinación de cómo descubrir la verdad sobre la base de las pruebas, que modernamente se propone que sea identificada aplicando un método controlable, que permita la efectiva participación de las partes, incluso discutir la eficacia de las pruebas aún antes de la evaluación judicial(40). También inciden las implicaciones culturales en las regulaciones normativas de los diversos aspectos de la admisibilidad —o inadminisibilidad-, las modalidades de la práctica y la valoración de las pruebas.

Claro que todo ello se inscribe en visiones valorativas más amplias, comprensivas del modo de sentir el derecho, y en especial la disciplina y el objeto del

(37) Marinoni, L. G. (2015). Tutela inhibitoria: la tutela de la prevención del ilícito (p. 1130). Así cómo desde lo sustancial resulta imprescindible el funcionamiento de una tutela inhibitoria destinada a suprimir la práctica, repetición y/o continuidad de conductas eventualmente dañosas, desde lo procesal deviene necesario desarrollar un trámite especial para garantizar la prestación de esa tutela preventiva (op. cit.). Más ampliamente: (2014). Tutela inhibitoria. Madrid-Barcelona-Bs.As.São Paulo: Marcial Pons. Lorenzetti, R. L. (1995). La tutela inhibitoria. Buenos Aires: La Ley (p. 1217), donde se resalta que tanto en el aspecto sustantivo como procesal se asista al nacimiento de herramientas de actuación preventiva, para evitar el daño antes de que éste se produzca e incursionar en el orden social para garantizar la prestación de la tutela.

(38) Peyrano, J. W. (2003). La acción preventiva. Buenos Aires: Lexis Nexis Abeledo-Perrot (pp. 9 y ss.). La consolidación de la tutela judicial preventiva supone la necesidad de abandonar una visión estrecha de la función jurisdiccional, cuando el poder administrador que tradicionalmente acaparaba la misión policial de prevención, se encuentra en reiterada por el clima neoliberal que impregna a las instituciones políticas (p. 13).

(39) Taruffo, M. (2007). Poderes probatorios de las partes y del juez en Europa. Rev. Iberoam. Der. Proc. (pp. 305 y ss., especialmente pp. 324-325); Taruffo, M. (2007). Cultura y proceso (pp. 202 y ss.).

(40) Taruffo, M. (1994). Modelli di prova e procedimento probatorio. Studi in onere di Vittorio Denti. Cedam, Padova (pp. 377 y ss. 393-395, 401 y ss.). 
proceso, en concordancia con la idea-fuerza del Estado Democrático de Derecho contemporáneo.

Desde esa perspectiva, habrá que convenir, en lo que aquí resulta pertinente, que parece evidente que las proposiciones del "privatismo" procesal han ido perdiendo paulatinamente la envergadura y consistencia de antaño. $\mathrm{O}$, al menos, se vienen desdibujando en su incidencia sobre ciertos segmentos de la actividad jurisdiccional, particularmente en los procesos que versan sobre derechos fundamentales "sensibles" prohijados por las constituciones y pactos humanitarios vida digna, salud, educación, vivienda, familia, menores, discapacitados, trabajo y seguridad social, derechos individuales y colectivos de consumidores y usuarios, del ambiente, de grupos desfavorecidos, y un largo etcétera que sigue abierto-. En todo ese ancho territorio la "publicización" ha avanzado notablemente, mientras siguen incólumes, con igual jerarquía, las garantías judiciales del contradictorio, debido proceso y aledañas, incluyendo el principio dispositivo.

En segundo lugar, resulta no menos cierto - como señalan quienes recelan de la creciente publicización-, que el activismo judicial no puede llevarse al extremo del avasallamiento del derecho de defensa y del contradictorio de las partes. El principio de legalidad formal sigue constituyendo un vallado insorteable, último bastión de la seguridad jurídica. Es aquí donde se insertan las más actuales concepciones que se asientan en el principio o máxima de cooperación o colaboración, ya aludidas.

A) Pertinencia y admisibilidad. Prueba decisiva

Bajo el régimen tradicional, como un avance excepcional de los poderes instructorios del juez, se le confía disponer sobre la pertinencia y admisibilidad de las pruebas. No serán admitidas aquellas que fueren manifiestamente improcedentes o superfluas o meramente dilatorias. Se persigue acelerar los desarrollos litigiosos, expurgando el proceso de medidas inconducentes.

Es una de las funciones típicas que se insertan en la audiencia preliminar y que se recoge en los ordenamientos que siguieran el modelo del CPC italiano de 1942 y otros semejantes.

Se trata de técnicas que tienden a la facilitación del progreso más acelerado del trámite por la descarga, en una etapa temprana, de medidas inoficiosas, innecesarias y, por ello mismo, costosamente improductivas. Con un objeto prevalente formal, bien han sido toleradas de todos modos desde una concepción dispositivista.

En cambio, el viraje hacia una cosmovisión superadora, que concibe el proceso como instrumento orientado a la búsqueda de la verdad de los hechos, como 
presupuesto ineficiente del objetivo de la sentencia intrínsecamente justa, trajo consigo un principio innovador. Al juez no solo se le reconoce poderes-deberes formales para rechazar pruebas impertinentes, superfluas o dilatorias, sino que, además, se le impone el deber activo, irrenunciable de ordenar aun oficiosamente todas las medidas probatorias decisivas para esclarecer la verdad de los hechos debatidos (41).

B) Distribución y adjudicación del onus probandi. El "ocaso" de las teorías sobre carga de la prueba y la concepción dinámica.

La doctrina tradicional se agotó en el análisis teórico de la carga de la prueba. Como lo explicó Arazi, el tema fue perdiendo paulatinamente relevancia, cayendo en el "ocaso" (Arazi, 2000, pp. 1041 y ss.). Sin embargo, se suscitó un nuevo interrogante ¿esas reglas estáticas son aplicables a todos los procesos, sin distinción alguna? Ya Couture propiciaba la flexibilización atribuyendo al juez apreciar las omisiones o deficiencias en la producción, incorporando una norma específica en su proyecto de 1945, que luego se trasegara al CGP uruguayo de 1989.

Se fue gestando de ese modo la denominada teoría de las cargas "interactivas", fluyentes o dinámicas, que suponen el poder genérico atribuido al juez para imponer excepcional y fundadamente, al margen de las reglas ordinarias de asignación, que la carga de la prueba corresponde sea asumida por aquella que se encuentra objetivamente en mejor posición para aportarla. Ha de verse que, en realidad, su fundamento y utilidad vincula con la concepción publicista del proceso como instrumento para la búsqueda de la verdad intrínseca, y particularmente cuando están en juego ciertos derechos "sensibles" de raigambre constitucional. A ello responden los artículos 710 y 1735 del CC y CN, en sintonía con normas similares de otras legislaciones (42).

(41) Es la señera doctrina sentada por la CSN a partir de los precedentes “Colalillo", Fallos 238:550, "Ohiler", Fallos 302:1611, y otros. El proceso civil no puede ser conducido en términos estrictamente formales (...), se trata del desarrollo de procedimientos destinados al establecimiento de la verdad objetiva, que es su norte". De ahí que no solo pueden, sino que deben, ordenar todas las diligencias que resulten necesarias para esclarecer la verdad de los hechos que resulten decisivos para la solución de la causa. En la misma línea de pensamiento, Arazi ha subrayado que, aun mediando negligencia de las partes, el juez tiene el deber de suplir la omisión a fin de esclarecer la verdad de los hechos, ordenando la producción de las pruebas que considere decisivas (1998). La prueba en el proceso civil. Teoría y práctica. Buenos Aires: La Rocca. 2a . pp. 41-44. Arazi, (1996). Los principios procesales y la prueba, en La prueba. Libro en memoria del Prof. Santiago Sentís Melendo. La Plata, (pp. 31-32, 34-35). Asimismo, Arazi, (2015). Derecho Civil y Comercial. Buenos Aires: RubinzalCulzoni, (pp. 391 y ss.).

(42) LEG española, artículo 217, n. 6. El nuevo CPC brasileño establece la distribución dinámica de la carga probatoria (artículos $373, \S 1^{\circ}, 357$, III). 
Por lo demás, la adjudicación del onus a la parte que se encuentra en mejores condiciones del producir la prueba, importa resaltar los deberes genéricos de colaboración procesal - principio o máxima de cooperación o colaboración- (Mitidiero, 2009, pp. 163 y ss.), erigido en pieza visceral de la concepción moderna del proceso (supra VI, d).

C) Valoración de la prueba

Una primera cuestión con implicancias ideológicas se plantea en torno a los sistemas de valoración. Como lo explicaba Cappelletti (2000, pp. 33, 83-84), el sistema de la prueba legal característico del procedimiento común europeo del medioevo, adoptado por los tribunales eclesiásticos e imperiales, ilustra de modo acabado la cristalización en el campo procedimental, no solo de una estructura política, social y económica jerárquica y desigualitaria (43) — la superioridad del aristócrata, del eclesiástico, del pudiente-, sino, además, el reflejo directo y la imposición normativa de un método de pensamiento apriorístico, formal, escolástico, que se correspondía con la cerrada mentalidad de la época. La contrapartida del método "científico" de inspiración galileana, de la libre apreciación probatoria, se nutre, claro, en una postura ideológica palmariamente opuesta (Capelletti, 2000, p. 84), que terminó por prevalecer. Bien que habrá que estar no menos en guardia, se alerta (44), por similares razones, contra un fenómeno más actual, aunque igualmente perverso, una especie de autoritarismo procesal moderno de tipo tecnocrático, quizá peor que el que caracterizaba aquella época de las pruebas irracionales y de las pruebas legales, cual es modernamente el encumbramiento de la denominada fase "científica" de la prueba. Fenómeno que se manifiesta en relación con la superlatividad atribuida al valor probatorio de la prueba científica, que viene a invertir de hecho la regla de no vinculatoriedad del dictamen experto y que conduce al peligro de transformar al proceso en una suerte de laboratorio, dominado por la técnica y neutro respecto de los valores que están en juego en la controversia y en los cuales se reflejan las valoraciones de la sociedad entera.

El paradigma protectorio de fuente constitucional que tutela de modo preferente ciertos derechos "sensibles" y situaciones de personas o grupos desfavorecidos, se plasma también en el sistema de evaluación de las pruebas. La igualación en concreto de las partes sustenta el sistema de presunciones legales que trasladan el onus probatorio para liberar a la parte tutelada $-v$.gr., en el proceso de trabajo y de la seguridad social, de familia, de consumidores y usuarios-.

(43) Se trata, como se ha destacado, del modelo "patrimonialista" en el pensamiento weberiano (Marioni, L. G. (2015). Cultura e previsibilidade do direito (pp. 431 y ss.).

(44) Denti, V. (1972). Significado de la expresión "cientificidad de la prueba". Rev. Der. Proc. Buenos Aires: La Ley (pp. 498-499). Denti, V. (1974). Estudios de derecho probatorio. Buenos Aires: Ejea (pp. 301-302). 
Otro aspecto igualmente candente es el vinculado con la valoración judicial de las pruebas y el peligro de la arbitrariedad(45), cuestión íntimamente ligada a la garantía del contradictorio. Los controles tendientes a evitar esas desviaciones no se limitan a verificar la fundamentación del propio decisorio (criterios de racionalidad), sino que se articulan y operan como técnicas normativas en los estadios anteriores de (a) la admisibilidad, así cuando se excluyen ciertas pruebas, (b) de los procedimientos de formación de las pruebas en buena parte dirigidos a garantizar in itinere la atendibilidad, y (c) aún al consagrarse reglas de prueba legal que excluyen la valoración discrecional del juez. Existen, además, controles procedimentales preventivos respecto de la decisión que posibilitan la intervención de las partes sobre todos los aspectos del iter probatorio que puedan influir sobre la decisión de mérito, y aún para discutir la propia atendibilidad de las pruebas. En ese sentido, se ha destacado la importancia del juego del contradictorio de las partes en cuanto permite indicar o al menos argumentar sobre los criterios según los cuales los poderes discrecionales del juez deberían ser ejercitados y también desarrollar previamente argumentaciones al respecto, en particular entre otros supuestos a propósito de las pruebas individualizadas como relevantes a los fines del pronunciamiento (46). También en este tramo relucen, sin duda, los principios colaborativos del proceso construido de modo participativo.

El control de la valoración judicial de las pruebas para salvaguardar su racionalidad y aventar la arbitrariedad, claro, no se dispensa en el juzgamiento de los derechos de tutela preferente. Así, por caso, tratándose del derecho a la salud si la sentencia muestras graves defectos de fundamentación(47); o prescindió de examinar el régimen legal aplicable y omitió exponer fundamentos razonados que sostengan jurídicamente la obligación de cobertura de las prestaciones pretendidas (48); o si se descartó sin razón suficiente circunstancias relevantes que conducían a la conclusión que no se observaba menoscabo de los derechos constitucio-

(45) La historia del derecho de las pruebas — afirma Taruffo- en todos los ordenamientos, podría ser leída como la historia de los intentos legislativos y doctrinarios para prevenir o al menos limitar el arbitrio al juez de los hechos en la valoración de las pruebas. Taruffo, (2002). La prueba de los hechos. Madrid: Trotta (p. 330).

(46) Taruffo, M. (2015). La prueba de los hechos (pp. 427 y ss.) La libre valoración implica que la eficacia de la prueba dependa de una selección discrecional del juez, y esa selección implica el riesgo de arbitrariedad. De ahí la necesidad de admitir que las partes puedan intervenir previamente adelantando y justificando sus propias hipótesis sobre la atendibilidad de las pruebas. Si bien el juez no está obviamente vinculado a esas hipótesis, sin embargo, ellas pueden constituir elementos de juicio pertinentes si se inspiran en criterios de racionalidad (pp. 431-434).

(47) CSN, 29-4-2014, “D., D. F. c. C.E.M.I.C.” (voto del Dr. Fayt).

(48) CSN, 18-3-2016, “S., D. c. Centro de Educación Médica”, donde se declaró que al examinar una reclamación fundada en el derecho a la salud no hay razones que justifiquen eximir o mitigar el deber de fundar las sentencias. 
nales relativos al resguardo del derecho a la salud y a la protección de las personas con discapacidad (49).

\section{Hacia una síntesis y en la búsqueda de un sistema de valores abarcador}

Bien que la pretensión de bosquejar un sistema de creencias con aspiraciones de superar las ideologías que tradicionalmente han campeado en el proceso civil pueda parecer ad initio un intento inevitablemente inútil, de todos modos, como cierre de estas reflexiones permítasenos proponer algunas consideraciones al respecto. Se trata, no obstante, del propósito del observador objetivo de encontrar, si existiere, una síntesis superadora de las antinomias, que se sustenta en las ideas y valores hoy prevalecientes, las líneas fundamentales del Estado Democrático de Derecho. Síntesis que, en definitiva, viene a perfilarse a partir de algunas - las principales-conclusiones que hasta aquí hemos intentado extraer. Y que -como se memoraba al comienzo recurriendo al pensamiento de Bobbio- supone tentar aproximaciones y pergeñar opciones superadoras a partir de una versión triádica, "terceras vías" de pensamiento que proliferan en el imaginario político, tanto como - agregamos- en el jurídico y procesal.

En primer lugar, parece evidente que las proposiciones del "privatismo" procesal han ido perdiendo paulatinamente la envergadura y consistencia de antaño, más allá de su recreación de la mano del neoliberalismo que se recicla en todo tiempo. $\mathrm{O}$, al menos, se vienen desdibujando en su incidencia sobre ciertos segmentos de la actividad jurisdiccional, particularmente en los procesos que versan sobre derechos fundamentales "sensibles" prohijados por las constituciones y pactos humanitarios — vida digna, salud, educación, vivienda, familia, menores, discapacitados, trabajo y seguridad social, derechos individuales y colectivos de consumidores y usuarios, del ambiente, de grupos desfavorecidos, y un largo etcétera que sigue abierto-. En todo ese ancho territorio la "publicización" ha avanzado notablemente, mientras siguen incólumes, con igual jerarquía, las garantías judiciales del contradictorio, debido proceso y aledañas, incluyendo el principio dispositivo. Se trata, entonces, del encumbramiento de los nuevos derechos y, particularmente la garantía fundamental de la tutela judicial eficiente - juez natural imparcial e independiente, acceso irrestricto a la jurisdicción, procedimiento y sentencia justa en tiempo razonable, medidas de urgencia en general-, que trae consigo nuevas concepciones de la jurisdicción, la acción y el proceso.

En segundo lugar, resulta no menos cierto - como señalan quienes recelan de la creciente publicización-, que el activismo judicial no puede llevarse al extremo del avasallamiento del derecho de defensa y del contradictorio de las partes. El

(49) CSN, 24-5-2016, “B., V. P. c. Obra Social del P.J. de la Nación”. 
principio de legalidad formal sigue constituyendo un vallado insorteable, último bastión de la seguridad jurídica.

Así crípticamente delineadas las clásicas posturas contrapuestas, cabe preguntarse cómo ha de incidir sobre ellas -0 , si se prefiere-qué nueva lectura les cabe bajo el tamiz de la concepción política del Estado Democrático de Derecho, expresión genuina de los valores contemporáneos. Se trata, entonces, de pensar el proceso civil en la perspectiva de los derechos fundamentales, como instrumento adecuado, eficaz y eficiente para tutelar los valores supremos.

Bajo este prisma asoma un factor de esencia: la concepción política de la democracia participativa, que se irradia novedosamente al propio poder jurisdiccional. Se denota entonces, por derivación si se quiere, la potencialidad institucional del Poder Judicial que, una vez impelido - por el ejercicio de la acción o pretensión- se torna un espacio privilegiado del discurso democrático, un "motor de democracia" participativa. El proceso civil pasa a ser entendido, entonces, como un modelo normativo basado en la institucionalización de procedimientos democráticos, y aún un paradigma cooperativo de administración de justicia. La participación protagónica del juez junto con la que, con igual rango, se adjudica a las partes colocadas en posición de recíproca paridad, confluyen en un debate bajo reglas de transparencia, para desembocar en la justa decisión del conflicto. Con lo que la actividad del juez, y aún el activismo procesal creativo, vienen a contribuir no solo a la legitimación democrática de aquellas decisiones, sino también a la del propio poder jurisdiccional.

De su lado, el principio constitucional del contradictorio adquiere ahora una nueva dimensión, como soporte de la democraticidad del procedimiento. Se entiende como una garantía de participación en sentido sustancial, no solo formal, concretándose en el derecho que se reconoce a cada una de las partes a influir en la formación de las decisiones, en el resultado de la jurisdicción. A su vez y como correlato, todos los pronunciamientos judiciales deben ser fundados, sustancialmente justificados; y desde luego, no pueden ser sorpresivos. La dimensión sustancial del contradictorio supone reconocer a las partes no solo el derecho de hablar sino el de ser oídas. En su significado más profundo expresa, en realidad, la exigencia general y constante de controlabilidad sobre el modo cómo el juez ejerce el poder conferido por el ordenamiento jurídico. Se trata del mismo poder de controlabilidad que en el Estado Democrático de Derecho corresponde al ciudadano y sus representantes, respecto de los actos políticos. En esa perspectiva, el contradictorio es el soporte y basamento nuclear a partir del cual se construye el concepto de proceso.

Las tradicionales visiones ideológicas contrapuestas del proceso civil se asentaban en la superada concepción decimonónica del proceso como relación jurídica, 
que emplazaba al juez en una posición de preeminencia en relación con la situación de sujeción de las partes. Precisamente de la crisis de esa concepción, que se contrapone a los postulados igualitarios que nutren y se irradian desde el actual Estado Democrático de Derecho, emerge un nuevo paradigma del proceso de matriz cooperativa y policéntrica, que se caracteriza y define como procedimiento en contradictorio. Un proceso que se construye entre todos, en el cual al juez no solo le corresponden poderes-deberes de dirección e instrucción, sino, además, de necesaria intercomunicación y diálogo con las partes. De modo que el proceso se va edificando entre todos en una perspectiva intersubjetiva y coparticipativa: más precisamente, de modo democrático. Premisa que implica no solo el deber del juez de examinar y pronunciarse, en sus decisiones, sobre todos y cada uno de los fundamentos relevantes invocados por las partes, sino que, además, le están vedadas las decisiones sorpresivas apoyadas en fundamentos que no se hubieren sometido antes al contradictorio - garantía de previsibilidad y no sorpresa-.

El presupuesto esencial de un contradictorio sustancial, fuerte, dinámico se irradia a todas las etapas del proceso y, si bien se ve, su actuación concreta termina por diluir, en buena medida, los principales ejes que sustentan las visiones ideológicas antagónicas que hemos analizado.

A) Quedan desdibujados roles atribuidos al juez y a las partes, ajustándose aquellos en un equilibrio dinámico en correlato con los mayores deberes de recíproca colaboración. Pervive el activismo, aunque queda enmarcado y condicionado por la virtualidad del contradictorio, aún en los conflictos sobre derechos o situaciones de tratamiento diferenciado.

B) El procedimiento se ajusta sin menoscabo de su adecuación por el juez, en los límites de la ley y siempre con observancia del contradictorio sustancial. Lo cual vale tanto, v.gr., para la decisión sobre cuestiones de orden público - presupuestos procesales, cosa juzgada, litispendencia-, cuanto para las cautelares, tutelas de urgencia y de evidencia. Más aún, igual condicionante reconocen los pronunciamientos de medidas oficiosas y aun las que se dictan en aplicación del principio iura novit curia.

C) En el procedimiento probatorio, el contradictorio se ejercita en cada una de las sucesivas etapas como contrapartida de los poderes del juez, de modo que se reconoce a las partes en relación con la prueba propuesta por la contraria y, con más razón, frente a la ordenada oficiosamente, las prerrogativas de: I) contestar su relevancia y oportunidad; II) participar en su asunción; III) deducir pruebas contrarias; IV) discutir su eficacia aún antes de las decisiones. Ningún elemento de hecho puede ser llevado a la decisión sin haber sido previamente conocido y discutido por las partes. Infringe igualmente el contradictorio las resoluciones judiciales que adjudican a una de las partes extemporánea o sorpresivamente la 
carga de la prueba — pruebas dinámicas o fluyentes—; siempre deberá conferírsele el derecho de oposición y la facultad de producir pruebas o contrapruebas.

De ese modo, hemos intentado dar testimonio de debates que siguen vivos, desde una visión objetivada útil para colocar sobre nuevos carriles las pujas ideológicas clásicas, mostrando cómo en el devenir histórico los múltiples entrecruzamientos y puntos de contacto han conducido, de modo quizás inevitable, a acercar posturas dicotómicas y, sobremanera, a impulsar la búsqueda de propuestas superadoras.

\section{Bibliografía}

Alvarado Velloso, A. (2004). Debido proceso vs. pruebas de oficio. Bogotá: Temis.

Andolina, I. y Vignera, G. (2994). Il modela costituzionale del processo civile italiano. Torino: Giappichelli (pp. 13 y ss.).

Arazi, R. (1996). Los principios procesales y la prueba. En Morello (coord.), La prueba. Libro en memoria del Prof. Santiago Sentís Melendo. La Plata: LEP (pp. 3132, 34-35).

Arazi, R. (1998). La prueba en el proceso civil. Teoría y práctica. Buenos Aires: La Rocca (pp. 41-44).

Arazi, R. (2000). El ocaso de las teorías sobre la carga de la prueba. Buenos Aires: La Ley (pp. 1041 y ss.).

Arazi, R. (2015). Derecho Civil y Comercial. Buenos Aires: Rubinzal-Culzoni (pp. 391 y ss.).

Arruda Alvim Wambier, T. y Otros (2015). Primeiros comentarios ao Novo Código de Processo Civi. Rev. dos Trib. São Paulo (pp. 641-644).

Baptista Da Silva, O. A. (1993). A "plenitud de defesa" no processo civil. En Figueiredo Teixeira (coord.), As garantías do cuidadâo na Justiça. São Paulo: Saraiva (pp. 163-164).

Baptista Da Silva, O. A. (2004). Processo e ideología: o paradigma racionalista. R. de Janeiro: Forense.

Barbosa Moreira, J. C. (1984). Breves reflexiones sobre la iniciativa oficial en materia de prueba, Libro Homenaje al Prof. Jaime Guasp. Granada: Comares (pp. 156 y ss.). 
Barbosa Moreira, J. C. (2006). La significación social de las reformas procesales. $R D P$. Buenos Aires: Rubinzal-Culzoni (pp. 439 y ss.).

Berizonce, R. O. (2017). Las estructuras cooperativas y consensuales de normatividad: ¿hacia la superación de la cultura del litigio? Buenos Aires: Rubinzal-Culzoni (pp. 61 y ss.).

Berizonce, R. O. (2018). Regulación procesal de las tutelas diferenciadas en la Constitución. Anales F.C.J y S., UNLP (pp. 835 y ss.).

Berizonce, R. O. y Ferrand, F. (2011). Lois modèles et Traditions nationales. Procedural Justice. XIV IAPL World Congress. Heidelberg (pp. 115-116).

Bobbio, N. (1995). Derecha e izquierda. Razones y significados de una distinción politica. Madrid: Taurus (pp. 49 y ss.).

Cabral, A. (2016). Convençôes processuais. Salvador: Jus Podivm (pp. 106 y ss.).

Camus, A. (2005). El hombre rebelde. Buenos Aires: Losada (pp. 289 y ss.).

Cappelletti, M. (1972). Aspectos sociales y políticos del procedimiento civil (reformas y tendencias evolutivas en la Europa occidental y oriental). En S. Sentís Melendo y T. A.

Banzhaf (trad. Proceso, ideologías y sociedad) (pp. 34 y ss., 83-90). Buenos Aires: Ejea.

Cappelletti, M. (1972). La oralidad y las pruebas en el proceso civil. Buenos Aires: Ejea. Sentís Melendo (trad.). Cap. I y II.

Cappelletti, M. (2002). La testimonianza della parte nell sistema dell'oralita. Milano: Dott. A. Giuffré. Banzhaf (trad.) La Plata: LEP.

Chiarloni, S. (1975). Introduzione allo studio del diritto processuale civile. Torino (pp. 24-15).

Chiarloni, S. (2010). Reflexiones microcomparativas sobre ideologías procesales y comprobación de la verdad. $R D P$. Santa Fe: Rubinzal-Culzoni (pp. 559 y ss.).

Cipriani, F. (2003). Batallas por la justicia civil. Ensayos. Lima: Cultural Curzo.

Cipriani, F. (2003). Il processo civile italiano tra efficienza e garanzie. Rev. Trim. Dir. e Proc. Civ. Milán: Giuffré.

Comoglio, L. P. (1994). I modelli di garanzia costituzionale del processo. Studi in onere di Vittorio Denti (pp. 297-381). 
Couture, E. J. (1958). Fundamentos del Derecho Procesal Civil. Buenos Aires: Depalma (pp. 144-145).

De Lazzari, E. (1996). La cautela material en Hacia una justicia más efectiva. En XVII Congreso Nacional de Derecho Procesal. Buenos Aires: La Ley (pp. 558 y ss.).

De Pinho, H. D. B. y Alves, T. M. (2015). O cooperaçâo no novo CPC. REDP. Recuperado de www.civilprocedurereview.com

De Souza, A. C. (2013). O principio da cooperaçâo. RePro No 225 (pp. 65 y ss.).

Denti, V. (1972). Significado de la expresión "cientificidad de la prueba". Rev. Der. Proc. (Argentina) No 4 (pp. 498-499). Buenos Aires: La Ley.

Denti, V.(1974). Estudios de derecho probatorio. Buenos Aires:Ejea (pp.301-302).

Dimarco, C. (2001). Instituçoes de Direito Processual Civil. São Paulo: Malheiros (p. 208).

Dimarco, C. (2001). O novo Código de Processo Civil brasileiro e a ordem processual civil vigente. RePro. São Paulo: Malheiros (pp. 63 y ss.).

Freitas Camara, A. (2015). Dimençâo processual do principio do debido proceso constitucional. Rev. Iberoam. Der. Procesal, Rev. São Paulo: dos Trib (pp. 17 y ss.).

Giussani, A. (2013). Alla ricerca dello spirito della sinistra degli anni 70 nella giustizia civile italiana. RePro. São Paulo (pp. 345 y ss.).

González Álvarez, R. (2014). De los orígenes del proceso al neoprocesalismo. En R. González Álvarez (coord.), Constitucionalismo y proceso. Tendencias contemporáneas. Lima: ARA (pp. 167 y ss.).

Greger, R. (2012). Cooperaçâo como principio processual. RePro. São Paulo (pp. 123 y ss.).

Judt, T. (2014). El peso de la responsabilidad. Buenos Aires: Aguilar (pp. 25, 26, 33).

Kochen, R. (2016). Introduçâo as raízes históricas do principio da cooperaçâo. RePro. São Paulo (pp. 75 y ss.).

Lorenzetti, R. L. (1995). La tutela inhibitoria. Buenos Aires: La Ley (p. 1217). 
Marinoni, L. G. (1993). Observaçôes a partir de uma visao da ideología no processo civil. Rev. Jurídica No 7 (p. 137). Curitiba.

Marinoni, L. G. (1996). Novas linheas do Processo Civil. São Paulo: Malheiros (pp. 75-77).

Marinoni, L. G. (2013). De la acción abstracta y uniforme a la acción adecuada a la tutela de los derechos. Rev. Peruana Der. Proc. Lima: Communitas (pp. 370 $-371)$.

Marinoni, L. G. (2014). Tutela inhibitoria. Madrid-Barcelona-Buenos Aires-São Paulo: Marcial Pons.

Marinoni, L. G. (2015). Cultura e privisibilidade do direito. RePro. São Paulo (pp. 431 y ss.).

Marinoni, L. G. y Arenhart, y Mitidiero, D. (2015). Novo curso de processo civil. São Paulo: Rev. dos Trib. (pp. 35 y ss.).

Mitidiero, D. (2009). Colaboración en el proceso civil. Lima: Communitas (pp. 163 y ss.).

Monroy Galvez, J. F. (2006). Y al final del día, ¿qué es el garantismo procesal civil? Rev. Iberoam. Der. Proc. (pp. 7 y ss.).

Morello, A. M. (1986-A). La jurisdicción protectora. Buenos Aires: JA (pp. 3005 y ss.).

Morello, A. M. (1986-C). Un nuevo modelo de justicia. Buenos Aires: La Ley (pp. 800 y ss.).

Morello, A. M. (1989). La Corte Suprema en acción. Buenos Aires: Abeledo-Perrot/LEP (pp. 11 y ss.).

Morello, A. M. (1998). Constitución y proceso. La nueva edad de las garantías jurisdiccionales. La Plata: LEP.

Morello, A. M. (2005). El proceso justo. Buenos Aires: Lexis Nexis/LEP (pp. 651 y ss.).

Nunes, G. E. S. (2016). Proceso civil democrático, contraditorio e novo Código de Processo Civil. RePro (pp. 15 y ss.).

Oteiza, E. D. (2013). América Latina. Cultura y proceso civil. En Proceso judicial y cultura. Una mirada global. Universidad de Medellín-FUTC (pp. 199 y ss.). 
Parra Quijano, J. (2004). Racionalidad e ideología de las pruebas de oficio. Bogotá: Temis (pp. 93 y ss.).

Peyrano, J. W. (1978). El proceso civil. Principios y fundamentos. Buenos Aires: Astrea (pp. 83, 337 y ss.).

Peyrano, J. W. (2003). La acción preventiva. Buenos Aires: Lexis Nexis AbeledoPerrot (pp. 9 y ss.).

Peyrano, J. W. (2008). Sobre el activismo judicial. Buenos Aires: La Ley (pp. 837 y ss.).

Pico Junoy, J. (2004). El derecho procesal entre el garantismo y la eficacia: un debate mal planteado. Rev. Iberoam. Der. Proc. (pp. 253 y ss.). Buenos Aires.

Pico Junoy, J. (2007). El juez y la prueba. Barcelona: Bosch (pp. 117 y ss.).

Proto Pisani, A. (1996). Lezioni di Diritto Processuale Civile. Napoli: Jovene ed. (pp. 5 y ss.).

Proto Pisani, A. (2015). Necessitá di scogliere i nodi e gli equivoci della espressione: tutela giurisdizionale diferenziata. RePro. São Paulo (pp. 281 y ss.).

Rawls, J. (1996). El liberalismo político. Barcelona: Grijalbo Mondadori (pp. 72-77).

Sabato, E. (2003). Apologías y rechazos. Buenos Aires: Seix Barral (p. 170).

Silveira, D. G. (2015). Direito ao contraditorio. RePro. São Paulo (pp. 69 y ss.).

Taruffo, M. (1994). Modelli di prova e procedimento probatorio. Studi in onere di Vittorio Denti. Padova: Cedam (pp. 377 y ss., 393-395, 401 y ss.).

Taruffo, M. (2002). La prueba de los hechos. Madrid: Trotta. Ferrer Beltrán (trad.) (p. 330).

Taruffo, M. (2007). Poderes probatorios de las partes y del juez en Europa. Rev. Iberoam. Der. Proc. Oteiza (trad.) (pp. 305 y ss.).

Taruffo, M. (2009-A). La justicia civil. Páginas sobre la justicia civil. MadridBarcelona-Buenos Aires: Marcial Pons (pp. 177).

Taruffo, M. (2009-B). Cultura y proceso en Páginas sobre la justicia civil. Madrid-Barcelona-Buenos Aires: Marcial Pons (p. 195). 
Taruffo, M. (2015). Ideologie e teorie della giustizia civile. RePro. São Paulo (pp. 49 y ss.). En versión castellana: Ideologías y teorías de la justicia civil, en Proceso judicial y cultura. Una mirada global. Univ. de Medellín, FUT. Ramírez Carvajal (trad.) (pp. 23 y ss.). Asimismo (2014). Constitucionalismo y proceso. Tendencias contemporáneas. González Álvarez (coord.). Lima: ARA. Cárdenas Rodríguez (trad.) (pp. 151 y ss.).

VV. AA. (2006). Proceso civil e ideología. Montero Aroca (coord.). Valencia: Tirant lo Blanch.

Zagrebelsky, G. (2005). El derecho dúctil. Trotta (pp. 9 y ss.).

Zanetti Junior, H. (2007). O modelo constitucional do processo civil brasileiro. R. de Janeiro: Lumen Juris.

\section{Jurisprudencia}

Fallos: 238:550.

Fallos: 302:1611. “D., D. F. c. C.E.M.I.C..”

CSN, 18-3-2016, “S., D. c. Centro de Educación Médica”.

CSN, 24-5-2016, "B., V. P. c. Obra Social del P.J. de la Nación".

Fecha de recepción: 06-03-2019 Fecha de recepción: 02-10-2019 